\title{
Hemşirelerin Kanıta Dayalı Hemşireliğe Yönelik Tutumlarının İncelenmesi
}

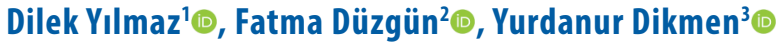

'Bursa Uludağ Üniversitesi, Sağlık Bilimleri Fakültesi, Hemşirelik Bölümü, Bursa, Türkiye ${ }^{2}$ Bursa Uludağ Üniversitesi, Sağlık Uygulama ve Araştırma Merkezi, Bursa, Türkiye

${ }^{3}$ Sakarya Üniversitesi Sağık Bilimleri Fakültesi, Hemşirelik Bölümü, Sakarya, Türkiye

Dilek Yılmaz, Öğr. Gör. Dr. Fatma Düzgün, Uzm. Hemş. Yurdanur Dikmen, Doç. Dr.

Iletişim:

Öğr. Gör. Dr. Dilek Yılmaz Bursa Uludağ Üniversitesi, Sağlık Bilimleri Fakültesi, Hemşirelik Bölümü, Bursa, Türkiye Tel: +90 2242942454

E-Posta:dilekk@uludag.edu.tr

Gönderilme Tarihi : 06 Şubat 2018

Revizyon Tarihi : 19 Mart 2018

Kabul Tarihi $\quad$ : 21 Mart 2018
ÖZET

Amaç: Bu araştırmanın amacı hemşirelerin kanıta dayalı hemşireliğe yönelik tutumlarııın incelenmesidir.

Çalışma Planı: Tanımlayııı ve kesitsel olarak planlanan bu araştırmanın örneklemini; Marmara Bölgesi'nde bulunan bir üniversite hastanesinin dahili ve cerrahi kliniklerinde çalışan ve araştırmaya gönüllü olarak katılmayı kabul eden 200 hemşire oluşturmuştur. Araştırmanın verileri, "Hemşire Tanıtım Formu" ve "Kanıta Dayalı Hemşireliğe Yönelik Tutum Ölç̧ği (KDHYTö)" kullanılarak toplanılmıştır. Verilerin değerlendirilmesinde sayı, yüzde, ortalama ve standart sapma ile Mann-Whitney U Testi ve Kruskal Wallis Testi kullanıımıştır.

Bulgular: Araştırmaya katılan hemşirelerin yaş ortalaması $36.60 \pm 6.82$ yıl olup, $\% 78.5^{\prime}$ inin evli, $\% 77.5^{\prime}$ inin lisans mezunu olduğu, \%85'inin servis hemşiresi olarak görev yaptığı, \%75'inin mesleki bilimsel toplantılara katıldığı, \%81.5'inin mesleki yayınları/ araştııma sonuçlarını takip etmediği belirlenmiştir. Hemşirelerin KDHYTÖ toplam puan ortalaması $46.36 \pm 3.95$, "Kanıta Dayalı Hemşireliğe Yönelik İnanç ve Beklentiler" alt boyut puan ortalaması 28.30 \pm 3.90 , "Kanıta Dayalı Uygulama Niyeti" alt boyut puan ortalaması $10.55 \pm 1.93$, "Kanıta Dayalı Hemşirelikle Il gili Duygular" alt boyut puan ortalaması ise $7.51 \pm 2.45$ olarak saptanmıştır. Hemşirelerin medeni durumları ve eğitim düzeyleri ile inanç ve beklentiler alt boyutu puan ortalamaları, bilimsel toplantılara katılma durumları ve eğitim düzeyleri ile duygular alt boyutu puan ortalamaları, çalışma durumları ile uygulama niyeti alt boyutu puan ortalamaları, mesleki yayınları düzenli takip etme durumları ile uygulama niyeti alt boyutu ve KDHYTö toplam puan ortalamaları arasında anlamlı bir fark bulunmuştur $(p<0.05)$.

Sonuç: Bu araştırma sonucunda; hemşirelerin kanıta dayalı hemşireliğe yönelik tutumlarııın orta düzeyde olduğu bulunmuştur.

Anahtar sözcükler: Hemşire, kanıta dayalı hemşirelik, tutum

\section{AN INVESTIGATION INTO NURSES' ATTITUDES TOWARDS EVIDENCE-BASED NURSING}

\section{ABSTRACT}

Aim: This study was conducted to investigate the attitudes of nurses towards evidence-based nursing.

Study Design: This descriptive and cross-sectional research involved 200 nurses working in the internal and surgical clinics of a university hospital in the Marmara Region, who voluntarily participated in the research. The study data were collected by using the "Nurse Presentation Form" and the "Attitude Scale for evidence-based Nursing (ASEBN)". The Mann-Whitney U Test, Kruskal Wallis Test, absolute numbers, percentage, mean and standard deviation were employed in evaluating the data.

Results: The average age of the nurses participating in the survey was $36.60 \pm 6.82$ years, of whom $78.5 \%$ were married, $77.5 \%$ were undergraduates, $85 \%$ were nurses in service, $75 \%$ participated in professional scientific meetings, and $85 \%$ did not actively follow professional publications or research results. The average score for the ASEBN was $46.36 \pm 3.95$. The "Beliefs and Expectations for the Evidence-Based Nursing" subscale mean score was $28.30 \pm 3.90$, the "Evidence-Based Application Intention" subscale mean score was $10.55 \pm 1.93$, and the "Feelings Related to evidence-based Nursing" subscale mean score was $7.51 \pm 2.45$. The following statistically significant differences within the ASEBN total mean scores were noted; marital status and nurses' level of education with the mean scores on the beliefs and expectations subscale, status regarding participation in scientific meetings with nurses' level of education and the mean scores of the emotions subscale, working status and application intention subscale, following professional publications and the application intention subscale $(p<0.05)$.

Conclusion: From this research, nurses were found to have moderately positive attitudes towards evidence-based nursing.

Key words: Nurse, evidence-based nursing, attitude. 
K anıt, sağlık bakım sistemindeki karar vericilerin ulaşabildiği, uygulamanın bilimsel değerlendirmesine dayanan bilgidir (1). Kanıta dayalı uygulama ise konuyla ilgili literatürü araştırma, bu araştırma sonuçlarını değerlendirme ve bunlara dayanarak karar vermeyi içeren bir klinik problem çözme sürecidir (2). Ayrıca kanıta dayalı uygulama, sistematik araştırma ile elde edilen en iyi araştırma kanıtının kişisel deneyim, klinik pratikle elde edilen klinik karar verme yeteneği ve hastanın değer ve tercihleriyle bütünleştirilmesi şeklinde de tanımlanmaktadır (3). Bu terim ilk kez 1992 yılında literatürde yer almaya başlamış ve daha sonra hemşirelik alanındaki çalışmalarda önemi giderek artmaya devam etmiştir $(2,4)$.

Kanıta dayalı hemşirelik, bakım ortamlarında hastaların tercihlerini, hemşirelerin klinik uzmanlıklarını ve eldeki en iyi kanıtları kullanarak bunlar sonucunda karar almaları süreci olarak tanımlanmaktadır (5). Kanıta dayalı uygulamalar, pek çok disiplinde var olduğu gibi son yıllarda hemşirelerin de yakından ilgilendiği bir konu haline gelmiştir (6). Kanıta Dayalı Hemşirelik, ilk olarak Kanada, ABD, İngiltere ve Avustralya gibi gelişmiş ülkelerde tartışılmaya başlanmıştır (7). Ülkemizde ise kanıta dayalı uygulama konusu ilk kez 2000 yılında gündeme gelmiştir (8).

Hemşirelik uygulamalarının asıl amacı, kanıta dayalı uygulama için sağlam bir temel oluşturmak ve bu temelin hemşireler için en iyi şekilde kullanmasını sağlamaktır (9). Genellikle uygulamaların geleneğe dayalı gerçekleştirildiği hemşirelik mesleğinde, eğitim düzeyi arttıkça uygulamaların kanıt temelli olması gereksinimi de giderek artmaya devam etmektedir $(6,10)$. Kanıta dayalı hemşirelik son yirmi yılda sağlık siteminin ana politikalarından birisi olmuş ve birçok ülkede kararların kanıta dayalı olması benimsenmiş, kanıta dayalı uygulama rehberleri geliştirilmiştir (11). Literatürde; hemşirelik bakımının kalitesini artırmak, klinik uygulamalarda ve hasta bakım sonuçlarında fark yaratmak, bakımı standardize etmek ve hasta memnuniyetini arttırmanın ancak kanıt temelli uygulamalar sayesinde mümkün olabileceği bildirilmektedir $(10,12,13)$.

Günümüzde artan iletişim teknolojileri kullanımı ile birlikte bilgiye kolay ulaşım ve yeni teknolojik gelişmelerin hayatımıza girmesi hastaların beklentilerini de yükseltmiştir (14). Çağdaş hemşirelik uygulamalarında klinik karar verme sürecinde kanıta dayalı uygulamalar neredeyse bir zorunluluk haline gelmiştir (2). Sağlık kuruluşlarında en kalabalık grup olan hemşirelerin, en iyi kanıtı tanımlamak ve uygulamalarına aktarmak için kanıta dayalı uygulamaları kavramaları gerekmektedir. Hemşirelerin kanıta dayalı uygulama konusunda tutumlarının belirlenmesi, kanıta dayalı hemşirelik uygulamalarının arttırılması ile ilgili stratejilerin geliştirilmesine yardımcı olacaktır. Kanıta dayalı hemşirelik sürecini hızlandıracak stratejilerin geliştirilebilmesi için ise atılacak ilk adım hemşirelerin konu ile ilgili tutumlarının bilinmesidir (15). Konuyla ilgili hemşirelerin kanıta dayalı tutumlarını ve görüşlerini değerlendiren uluslararası düzeyde çalışmaların olmasına rağmen (11,16-20), ülkemizde yapılan ulusal araştırma sayısının çok sınırlı sayıda olduğu görülmüştür $(21,22)$. Bu doğrultuda böyle bir araştırmanın yapılmasına gerek duyulmuştur.

Bu araştırma, bir üniversite hastanesinde çalışan hemşirelerin kanıta dayalı hemşireliğe yönelik tutumlarını incelemek amacıyla yapılmıştır.

\section{Yöntem}

Araştırmanın şekli

Bu araştırma tanımlayıcı ve kesitsel bir çalışma olarak planlanmıştır.

\section{Araştırmanın evren ve örneklemi}

Araştırma evrenini, Mayıs 2017-Ağustos 2017 tarihleri arasında Marmara Bölgesinde bulunan bir üniversite hastanesinin dahili ve cerrahi kliniklerinde çalışan 250 hemşire oluşturmuştur. Araştırmanın örneklemini, araştırmanın yapıldığı dönemde ulaşılabilen ve araştırmaya katılmayı kabul eden 200 hemşire oluşturmuştur (Katılım oranı: \%80). Araştırmanın tek merkezde yürütülmesi, sadece dahili ve cerrahi kliniklerde çalışan hemşirelerle yapılması ve veri toplama formlarında yer alan soruların hemşirelerin ifadelerine dayalı olması araştırmanın sınırlılıklarını oluşturmuştur.

\section{Verilerin toplanması veya veri toplama araçları}

Araştırma verilerinin toplanılmasında hemşirelerin tanıtıcı bilgilerini içeren 8 sorudan oluşan (yaş, cinsiyet, medeni durum, eğitim durumu, çalışma süresi, mesleki bilimsel toplantılara katılma durumu, herhangi bir mesleki derneğe üye olma durumu ve mesleki yayınları takip etme durumu) "Hemşire Tanıtım Formu"ve"Kanıta Dayalı Hemşireliğe Yönelik Tutum Ölçeği (KDHYTÖ)" kullanılmıştır.

Kanıta Dayalı Hemşireliğe Yönelik Tutum Ölçeği (KDHYTÖ): Hemşirelerin kanıta dayalı hemşireliğe yönelik tutumlarını ölçmek amacıyla 2011 yılında İspanyada Ruzafa-Martinez ve arkadaşları tarafından geliştirilmiş (18), ülkemizde geçerlik ve güvenirlik çalışması 2015 yılında Ayhan ve arkadaşları (21) tarafından yapılmıştır. Ölçek, 15 maddeden ve üç alt boyuttan oluşmaktadır. 
Maddelerin sekizi olumlu $(1,2,5,7,9,11,13$ ve 14 . maddeler) yedisi olumsuz $(3,4,6,8,10,12$ ve 15 . maddeler) ifade içermekte; olumsuz maddeler ters çevrilerek kodlanmaktadır. Beşli likert tipine ( $1=$ hiç katılmıyorum, 2=katılmıyorum, 3=biraz katılıyorum, 4=katılıyorum, $5=$ tamamen katılıyorum) göre hazırlanan ölçekten en düşük 15, en yüksek 75 puan alınmaktadır. Ölçekten yüksek puan alınması kanıta dayalı hemşireliğe yönelik tutumun olumlu olduğunu göstermektedir. Özgün ölçeğin güvenirlik katsayısı $\mathrm{a}=0.85^{\prime}$ tir. Alt boyut güvenirlik katsayıları, İnanç Alt Boyutu için $a=0.86$, Uygulama Niyeti Alt Boyutu için $a=0.63$, Duygular Alt Boyutu için $a=0.70$ 'dir (18). Bu araştırmada ölçeğin Cronbach Alfa iç tutarlılık katsayısı 0.89, alt boyutları için Cronbach Alfa iç tutarlılık katsayıları 0.70 ile 0.89 arasında hesaplanmıştır.

Kanıta Dayalı Hemşireliğe Yönelik Tutum Ölçeği (KDHYTÖ)'nin Alt Boyutları:

Kanıta Dayalı Hemşireliğe Yönelik İnanç ve Beklentiler Alt Boyutu; hemşirelerin klinik çalışmalarda kanıta dayalı hemşireliğin yararları ile ilgili inanç ve beklentilerine ilişkin maddeleri içermektedir $(1,2,7,9,11,13,14$. maddeler).

Kanıta Dayalı Uygulama Niyeti Alt Boyutu; hemşirelerin kanıta dayalı uygulamaları yapma davranışları veya niyetleri; algılanan engelleri, iş yükü ve eğitim için ayrılan sürenin kanıta dayalı hemşirelik için kullanılmasına ilişkin maddeleri içermektedir $(3,5,6,12$. maddeler).

Kanıta Dayalı Hemşirelikle Illgili Duygular Alt Boyutu; kanıta dayalı hemşireliğe verilen önem düzeyini, kanıta dayalı hemşireliğin klinik uygulamada kullanılmasında sağlanan yararları ve hemşirelerin konuyla ilgili duygularına ilişkin maddeleri içermektedir $(4,8,10,15$. maddeler) (21).

\section{Verilerin değerlendirilmesi}

Araştırma verilerinin değerlendirilmesi SPSS (Statistical Package For Social Science) 22.0 paket programı kullanılarak yapılmıştır. Verilerin analizinde sayı, yüzde, ortalama ile araştırma verilerinin normal dağılım göstermediği belirlendiği için Mann-Whitney U Testi, Kruskal Wallis Testi ve Spearman Korelasyon Analizi kullanılmıştır. İstatistiksel anlamlılık düzeyi 0.05 olarak belirlenmiştir.

\section{Araştırmanın etik boyutu}

Araştırmanın yürütülmesi için öncelikle ülkemizde Türkçe geçerlik ve güvenirlik çalışmasını yapan yazardan e-mail yoluyla yazılı izin alınmıştır. Ayrıca üniversite etik kurulundan (Karar No: 2017-8/14), araştırmanın yapıldığı kurumdan yazılı izin ve hemşirelerden sözlü ve yazılı onam alınmıştır.

\section{Bulgular}

Araştırmaya katılan hemşirelerin yaşortalaması $36.60 \pm 6.82$ yıl olup, \%94'ünün kadın, \%78.5'inin evli, \%77.5'inin lisans mezunu olduğu, \%57'sinin dahili kliniklerde çalıştığı, \%85'inin servis hemşiresi olarak görev yaptığı, çalışma süresinin 13.68 7.31 yıl olduğu, \%75'inin mesleki bilimsel toplantılara katıldığı, \%60'ının herhangi bir mesleki derneğe üye olmadığı, \%81.5'inin mesleki yayınları/araştırma sonuçlarını takip etmediği belirlenmiştir (Tablo 1).

Araştırmaya dahil olan hemşirelerin KDHYTÖ toplam puan ortalaması ile alt boyutlarının puan ortalamaları Tablo 2'de gösterilmiştir. Hemşirelerin KDHYTÖ toplam puan

Tablo 1. Hemşirelerin tanıtıcı özellikleri

\begin{tabular}{|c|c|c|}
\hline Özellikler & $n$ & $\%$ \\
\hline \multicolumn{3}{|c|}{ Yaş (Ort $\pm S S)(36.60 \pm 6.82 \mathrm{yll})$} \\
\hline \multicolumn{3}{|c|}{ Çalışma Süresi (Ort \pm SS) (13.68 \pm 7.31 yıl) } \\
\hline \multicolumn{3}{|l|}{ Cinsiyet } \\
\hline Kadın & 188 & 94.0 \\
\hline Erkek & 12 & 6.0 \\
\hline \multicolumn{3}{|l|}{ Medeni Durum } \\
\hline Evli & 157 & 78.5 \\
\hline Bekar & 43 & 21.5 \\
\hline \multicolumn{3}{|l|}{ Eğitim Durumu } \\
\hline Lise & 9 & 4.5 \\
\hline Önlisans & 14 & 7.0 \\
\hline Lisans & 155 & 77.5 \\
\hline Lisansüstü & 22 & 11.0 \\
\hline \multicolumn{3}{|l|}{ Çalıştığı Klinik } \\
\hline Dahili & 114 & 57.0 \\
\hline Cerrahi & 86 & 43.0 \\
\hline \multicolumn{3}{|l|}{ Çalışma Pozisyonu } \\
\hline Servis Hemşiresi & 170 & 85.0 \\
\hline Sorumlu Hemşire & 30 & 15.0 \\
\hline \multicolumn{3}{|c|}{ Bilimsel Toplantılara Katılma Durumu } \\
\hline Evet & 150 & 75.0 \\
\hline Hayır & 50 & 25.0 \\
\hline \multicolumn{3}{|c|}{$\begin{array}{l}\text { Herhangi Bir Mesleki Derneğe } \\
\text { Üye OIma Durumu }\end{array}$} \\
\hline Evet & 80 & 40.0 \\
\hline Hayır & 120 & 60.0 \\
\hline \multicolumn{3}{|c|}{ Mesleki Yayınları Takip Etme Durumu } \\
\hline Evet & 37 & 18.5 \\
\hline Hayır & 163 & 81.5 \\
\hline TOPLAM & 200 & 100.0 \\
\hline
\end{tabular}




\begin{tabular}{|c|c|c|}
\hline \multirow[t]{2}{*}{ Ölçekler } & $\begin{array}{l}\text { Ölçekten Alınan } \\
\text { Alt ve Üst Değer }\end{array}$ & $\begin{array}{l}\text { Her Bir Ölçek Için } \\
\text { Ortalama Puanlar }\end{array}$ \\
\hline & & Ort $\pm S D$ \\
\hline $\begin{array}{l}\text { "Kanıta Dayalı Hemşireliğe } \\
\text { Yönelik İnanç ve Beklentiler" }\end{array}$ & $14-35$ & $28.30 \pm 3.90$ \\
\hline "Kanıta Dayalı Uygulama Niyeti" & $6-16$ & $10.55 \pm 1.93$ \\
\hline $\begin{array}{l}\text { "Kanıta Dayalı Hemşirelikle İlgili } \\
\text { Duygular" }\end{array}$ & $4-15$ & $7.51 \pm 2.45$ \\
\hline KDHYTÖ Toplam Puan & $24-58$ & $46.36 \pm 3.95$ \\
\hline
\end{tabular}

ortalaması 46.36 \pm 3.95 , “Kanıta Dayalı Hemşireliğe Yönelik İnanç ve Beklentiler" alt boyut puan ortalaması $28.30 \pm 3.90$, "Kanıta Dayalı Uygulama Niyeti" alt boyut puan ortalaması 10.55 \pm 1.93 , "Kanıta Dayalı Hemşirelikle İlgili Duygular" alt boyut puan ortalaması ise $7.51 \pm 2.45$ olarak saptanmıştır.

Araştırma kapsamına alınan hemşirelerin medeni durumları ve eğitim düzeyleri ile inanç ve beklentiler alt boyutu puan ortalamaları, bilimsel toplantılara katılma durumları ve eğitim düzeyleri ile duygular alt boyutu puan ortalamaları, çalışma durumları ile uygulama niyeti alt boyutu puan ortalamaları, mesleki yayınları düzenli takip etme durumları ile uygulama niyeti alt boyutu ve KDHYTÖ toplam puan ortalamaları arasında anlamlı bir fark bulunmuştur $(p<0.05)$ (Tablo 3).

Diğer yandan, hemşirelerin yaş ve meslekte çalıştıkları süre ile KDHYTÖ toplam puan ortalaması arasında anlamIı bir ilişki saptanmamıştır (sırasıyla; $r$ : $-0.059, \mathrm{p}=0.410 ; r=$ $-0.075, p=0.291$ ).

\section{Tartışma}

Hemşirelik uygulamalarının kanıta dayalı olması bakım kalitesini ve bakım sonuçlarını iyileştirmek, klinik uygulamalarda ve hasta bakım sonuçlarında fark yaratmak, bakımı standardize etmek, hemşire ve hasta memnuniyetini artırmak gibi sonuçlar açısından önemlidir. Kanıta dayalı uygulamalar ayrıca hemşirelik uygulamalarının bilimselleşmesini sağlamaktadır $(23,24)$. Arslan ve arkadaşlarının (2015) yaptıkları bir çalışmada; hemşireler kanıta dayalı uygulamaların hasta bakım kalitesini arttırdığı, bilimsel olarak yapılan uygulamaların doğruluğu kanıtladığını ve yasal olarak hemşireleri de koruduğu için oldukça yararI bulduklarını belirtmişlerdir (2). Merih ve arkadaşlarının (2017) çalışmasında da ebe ve hemşirelerin tamamına yakını klinik uygulama alanlarında kanıta dayalı uygulamaların gerekli olduğunu ifade etmişlerdir (24).
Hemşirelerin kanıta dayalı uygulama konusunda tutumlarının belirlenmesi, kanıta dayalı hemşirelik uygulamalarının arttırılmasına yönelik olarak stratejilerin geliştirilmesine katkı sağlaması açısından oldukça önemlidir. Bu anlamda, bir üniversite hastanesinin dahili ve cerrahi kliniklerde çalışan hemşirelerin kanıta dayalı hemşireliğe yönelik tutumlarının incelenmesi amacıyla yapmış olduğumuz bu çalışma sonucunda; hemşirelerin KDHYTÖ toplam puan ortalamasının $46.36 \pm 3.95$ olduğu bulunmuştur (Tablo 2 ). Ölçekten alınabilecek en düşük puanın 15, en yüksek puanın 75 olduğu düşünülürse, hemşirelerin kanıta dayalı hemşireliğe yönelik tutumlarının orta düzeyde olduğu söylenebilir. Ülkemizde yapılan çalışmalar incelendiğinde; Ayhan ve arkadaşlarının (2015) yaptıkları çalışmada, hemşirelerin KDHYTÖ toplam puan ortalaması 61.87 \pm 9.44 olarak saptanmıştır (21). Dikmen ve arkadaşları (2018) tarafından yoğun bakım ünitelerinde çalışan hemşirelerin yaptıkları çalışmada ise KDHYTÖ toplam puan ortalaması $57.20 \pm 9.06$ olarak belirlenmiştir (22). Yukarıdaki çalışma sonuçlarıyla karşılaştırıldığında; çalışmamıza katılan hemşirelerin KDHYTÖ toplam puanlarının, bu çalışma sonuçlarına göre daha düşük olduğu görülmektedir. Bu farklıığın, araştırmanın farklı bölgeler ve farklı birimlerde çalışan hemşirelerle yapılmış olmasından kaynaklanabileceği düşünülmüştür. Çünkü yaptığımız bu çalışmaya sadece dahili ve cerrahi kliniklerde çalışan hemşireler dahil edilmiş olup, yoğun bakım ünitelerinde, poliklinik vb. gibi diğer birimlerde çalışan hemşireler araştırma kapsamına alınmamıştır.

Araştırma sonucuna göre, hemşirelerin mesleki yayınları düzenli takip etme durumları ile uygulama niyeti alt boyutu ve KDHYTÖ toplam puan ortalamaları arasında anlamlı bir fark olduğu bulunmuştur (Tablo 3). Dikmen ve arkadaşlarının (2018) çalışmasında da bilimsel araştırma sonuçlarını ve mesleki dergileri düzenli takip eden hemşirelerin, diğer hemşirelere göre kanıta dayalı hemşireliğe yönelik tutumlarının anlamlı düzeyde yüksek olduğu saptanmıştır (22). Çalışma sonucumuz bu araştırma sonucuyla benzerlik taşımaktadır. Sürekli yenilenen bilimsel araştırma sonuçları hemşirelik bakımının kalitesine bir dinamizm getirir ve bu araştırma sonuçlarının uygulamaya aktırılmasının yollarından biri de bilimsel dergilerdir. Araştırma sonuçlarını/mesleki yayınları takip eden hemşirelerin, kanıta dayalı uygulamaları klinik alana yansıtabileceklerinden dolayı, kanıta dayalı hemşireliğe ilişkin tutumlarının yüksek olması da beklenen bir bulgudur.

Sürekli yenilerek bakımın içeriğine ve niteliğine dinamiklik kazandıran araştırma sonuçlarının hemşirelere ulaştırabilme yollarından biri de mesleki bilimsel toplantılardır (25). Çalışma sonucuna göre, bilimsel toplantılara katılan 
Tablo 3. Hemşirelerin tanıııı özellikleri ile KDHYTÖ alt boyutlarına ait puan ortalamalarının dağılımı $(n=200)$

\begin{tabular}{|c|c|c|c|c|}
\hline & Inanç ve beklentiler & Uygulama niyeti & Duygular & KDHYTÖ \\
\hline \multicolumn{5}{|l|}{ Cinsiyet } \\
\hline Kadın & $28,31 \pm 3,82$ & $10,55 \pm 1,88$ & $7,46 \pm 2,43$ & $46,33 \pm 3,87$ \\
\hline Erkek & $28,08 \pm 5,26$ & $10,50 \pm 2,64$ & $8,25 \pm 2,63$ & $46,83 \pm 5,20$ \\
\hline Anlamlılık derecesi & $\begin{array}{l}\text { Z: }-0,078 \\
\text { p: } 0,938\end{array}$ & $\begin{array}{l}\text { Z: }-0,546 \\
\text { p: } 0,585\end{array}$ & $\begin{array}{l}\mathrm{Z}:-1,034 \\
\mathrm{p}: 0,301\end{array}$ & $\begin{array}{l}\text { Z: }-0,093 \\
\text { p: } 0,926\end{array}$ \\
\hline \multicolumn{5}{|l|}{ Medeni durum } \\
\hline Evli & $28,12 \pm 3,42$ & $10,54 \pm 1,92$ & $7,56 \pm 2,34$ & $46,22 \pm 3,37$ \\
\hline Bekar & $28,95 \pm 5,30$ & $10,55 \pm 1,96$ & $7,34 \pm 2,81$ & $46,86 \pm 5,60$ \\
\hline Anlamlılık derecesi & $\begin{array}{l}\mathrm{Z}:-1,970 \\
\mathrm{p}: 0,049^{\star}\end{array}$ & $\begin{array}{l}\text { Z: }-0,367 \\
\text { p: } 0,714\end{array}$ & $\begin{array}{l}\text { Z: }-0,782 \\
\text { p: } 0,434\end{array}$ & $\begin{array}{l}\text { Z: }-1,721 \\
\text { p: } 0,085\end{array}$ \\
\hline \multicolumn{5}{|l|}{ Eğitim durumu } \\
\hline Lise & $26,22 \pm 272$ & $10,66 \pm 2,00$ & $6,59 \pm 3,01$ & $45,88 \pm 3,25$ \\
\hline Önlisans & $28,71 \pm 2,89$ & $9,85 \pm 1,40$ & $7,50 \pm 2,27$ & $46,07 \pm 3,19$ \\
\hline Lisans & $28,15 \pm 3,92$ & $10,67 \pm 1,99$ & $7,56 \pm 2,34$ & $46,38 \pm 4,13$ \\
\hline Lisansüstü & $29,90 \pm 4,30$ & $29,90 \pm 4,30$ & $9,00 \pm 2,54$ & $46,59 \pm 3,55$ \\
\hline Anlamlılık derecesi & $\begin{array}{l}\text { K-W: } 8,817 \\
\text { p: } 0,032^{*}\end{array}$ & $\begin{array}{c}\mathrm{K}-\mathrm{W}: 3,361 \\
\mathrm{p}: 0,339\end{array}$ & $\begin{array}{l}\text { K-W: } 8,845 \\
\text { p: } 0,031^{*}\end{array}$ & $\begin{array}{c}\text { K-W: } 0,886 \\
\text { p: } 0,829\end{array}$ \\
\hline \multicolumn{5}{|l|}{ Çalıştığı klinik } \\
\hline Dahili & $28,19 \pm 4,10$ & $10,46 \pm 1,85$ & $7,55 \pm 2,53$ & $46,21 \pm 4,03$ \\
\hline Cerrahi & $28,44 \pm 3,64$ & $10,66 \pm 2,03$ & $7,46 \pm 2,34$ & $46,56 \pm 3,86$ \\
\hline Anlamlılık derecesi & $\begin{array}{l}\text { Z: }-0,731 \\
\text { p: } 0,465\end{array}$ & $\begin{array}{l}\text { Z: }-0,225 \\
\text { p: } 0,822\end{array}$ & $\begin{array}{c}\text { Z: }-0,305 \\
\text { p: } 0,760\end{array}$ & $\begin{array}{c}\text { Z: }-0,196 \\
\text { p: } 0,845\end{array}$ \\
\hline \multicolumn{5}{|l|}{ Çalışma pozisyonu } \\
\hline Servis hemşiresi & $28,10 \pm 4,04$ & $10,70 \pm 1,97$ & $7,64 \pm 2,50$ & $46,44 \pm 4,09$ \\
\hline Sorumlu hemşire & $29,43 \pm 2,80$ & $9,70 \pm 1,39$ & $6,76 \pm 2,01$ & $45,90 \pm 3,07$ \\
\hline Anlamlılık derecesi & $\begin{array}{c}\text { Z: }-1,992 \\
\text { p: } 0,046\end{array}$ & $\begin{array}{l}\text { Z: }-2,735 \\
\text { p: } 0,006^{*}\end{array}$ & $\begin{array}{l}\text { Z: }-1,627 \\
\text { p: } 0,104\end{array}$ & $\begin{array}{l}\text { Z: }-1,190 \\
\text { p: } 0,234\end{array}$ \\
\hline \multicolumn{5}{|c|}{ Bilimsel toplantılara katılma durumu } \\
\hline Evet & $28,64 \pm 3,73$ & $10,58 \pm 2,00$ & $8,26 \pm 2,25$ & $46,49 \pm 4,15$ \\
\hline \multirow[t]{2}{*}{ Hayır } & $27,26 \pm 4,25$ & $10,46 \pm 1,70$ & $7,26 \pm 2,47$ & $45,98 \pm 3,31$ \\
\hline & $\begin{array}{l}Z:-1,855 \\
p: 0,064\end{array}$ & $\begin{array}{c}z:-0,113 \\
\text { p: } 0,910\end{array}$ & $\begin{array}{l}z:-2,750 \\
p: 0,006^{*}\end{array}$ & $\begin{array}{c}z:-0,628 \\
p: 0,530\end{array}$ \\
\hline \multicolumn{5}{|c|}{ Herhangi bir mesleki derneğe üye olma durumu } \\
\hline Evet & $28,90 \pm 3,32$ & $10.23 \pm 1.74$ & $7,17 \pm 2,55$ & $46,31 \pm 3,5$ \\
\hline \multirow[t]{2}{*}{ Hayır } & $27,90 \pm 4,21$ & $10,75 \pm 2,02$ & $7,74 \pm 2,36$ & $46,40 \pm 4,32$ \\
\hline & $\begin{array}{c}Z:-1,578 \\
p: 0,115\end{array}$ & $\begin{array}{l}z:-2,009 \\
p: 0,045\end{array}$ & $\begin{array}{l}z:-1.861 \\
p: 0.063\end{array}$ & $\begin{array}{c}z:-0,784 \\
p: 0,433\end{array}$ \\
\hline \multicolumn{5}{|c|}{ Mesleki yayınları takip etme durumu } \\
\hline Evet & $28,59 \pm 4,74$ & $9,62 \pm 1,38$ & $6,86 \pm 2,76$ & $46,65 \pm 4,05$ \\
\hline \multirow[t]{2}{*}{ Hayır } & $28,23 \pm 3,70$ & $10,76 \pm 1,98$ & $7,66 \pm 2,36$ & $45,08 \pm 3,22$ \\
\hline & $\begin{array}{c}\text { Z: }-1,158 \\
\text { p: } 0,247\end{array}$ & $\begin{array}{l}\text { Z: }-3,379 \\
\text { p: } 0,001^{*}\end{array}$ & $\begin{array}{c}\mathrm{Z}:-1,820 \\
\mathrm{p}: 0,069\end{array}$ & $\begin{array}{l}\text { Z: }-2,212 \\
\text { p: } 0,027^{*}\end{array}$ \\
\hline
\end{tabular}

${ }^{*} p<0.05$ 
ve eğitim düzeyi yüksek olan hemşirelerin diğer hemşirelere göre duygular alt boyutu puan ortalamalarının anlamlı düzeyde yüksek olduğu bulunmuştur. Dikmen ve arkadaşları (2018) ile Ayhan ve arkadaşlarının (2015) yaptıkları çalışmalarda; bilimsel toplantılara katılan hemşirelerin KDHYTÖ puan ortalaması, bilimsel toplantılara katılmayan hemşirelerin puan ortalamasından anlamlı olarak yüksek bulunmuştur $(22,25)$. Bizim çalışmamızda bilimsel toplantılara katılan hemşirelerin KDHYTÖ puan ortalaması, katılmayan hemşirelere göre yüksek olduğu fakat aralarında anlamlı bir fark olmadığı görülmüştür. "Kanıta Dayalı Hemşirelikle Illgili Duygular Alt Boyutu"; kanıta dayalı hemşireliğe verilen önem düzeyini, kanıta dayalı hemşireliğin klinik uygulamada kullanılmasında sağlanan yararları ve hemşirelerin konuyla ilgili duygularını içermektedir (21). Bu anlamda, bilimsel toplantılara katılan ve lisansüstü eğitim düzeyine sahip hemşirelerin, kanıta dayalı hemşireliğe önem vermeleri ve kanıta dayalı hemşireliği klinik uygulamada kullanmalarındaki duygularının yüksek olması olası bir sonuç olarak değerlendirmek mümkündür.

Araştırmaya dahil edilen lisansüstü eğitim düzeyine sahip hemşirelerin inanç ve beklentiler alt boyutu puan ortalamalarının diğer gruplara göre anlamlı düzeyde yüksek olduğu saptanmıştır (Tablo 3). Koehn ve Lehman (2008) tarafından yapılan bir çalışmada hemşirelerin eğitim düzeyinin kanıta dayalı hemşireliğe yönelik tutumlarını etkilediği ve etkinin yüksek lisans derecesine sahip hemşirelerden kaynaklandığını belirtmişlerdir (26). Fakat RuzafaMartinez ve arkadaşları (2011), Ayhan ve arkadaşları (2015) ile Dikmen ve arkadaşlarının (2018) çalışmalarında; hemşirelerin eğitim düzeylerinin, KDHYTÖ toplam puan ve alt boyutları puan ortalamalarını etkilemediği bulunmuştur $(18,21,22)$. Bu farklılıkların; araştırma örneklemine dahil edilen hemşirelerin örneklem özelliklerinin farklılık taşımasından kaynaklanabileceği düşünülmüştür.

Araştırmaya katılan dahili ve cerrahi kliniklerde çalışan hemşirelerin KDHYTÖ toplam puanlarının benzer olduğu

\section{Kaynaklar}

1. Şenyuva E. Hemşirelik eğitimi ve kanıta dayalı uygulamalar. F N Hem Derg 2016;24:59-65. [CrossRef]

2. Arslan $S$, Konuk Şener $D$, Küçük Ö. Pediatri kliniğinde çalışan hemşirelerin kanıta dayalı uygulamalara ilişkin görüşleri. Yıldırım Beyazıt Üniv Sağlık Bilim Fak Hem E-Derg 2015;3:1-9.

3. Ingersoll GL. Evidence-based Nursing: What It is and What It Isn't. Nurs Outlook 2000;48:151-2. [CrossRef]

4. Yava A, Tosun N, Çiçek H, Yavan T, Terakye G, Hatipoğlu S. Nurses' perceptions of the barriers to and the facilitators of research utilization in Turkey. App Nurs Res 2009;22:166-75. [CrossRef] görülmüştür (Tablo 3). Bu sonuç doğrultusunda çalışılan klinik türünün, hemşirelerin kanıta dayalı hemşireliğe ilişkin tutumlarını etkilemediği kanısına varılmıştır.

"Kanıta Dayalı Uygulama Niyeti Alt Boyutu"; hemşirelerin kanıta dayalı uygulamaları yapma davranışları veya niyetlerini yansıtmaktadır (21). Çalışma sonucuna göre; servis hemşiresi pozisyonunda çalışan hemşirelerin, sorumlu hemşirelere göre uygulama niyeti alt boyutu puan ortalamalarının yüksek olduğu bulunmuştur. Bu sonucun servis sorumlu hemşirelerin daha çok yöneticilik pozisyonunda çalışmalarından dolayı servis hemşirelerine kıyasla, klinikte kanıta dayalı uygulamaları yapma davranışlarının ve buna bağlı olarak oluşan niyetlerinin düşük olması şeklinde yorumlanmıştır. Bunun dışında; araştırmaya katılan hemşirelerin yaş ve meslekte çalıştıkları sürelerinin, kanıta dayalı hemşireliğe yönelik tutumlarını etkilemediği görülmüştür. Konuyla ilgili yapılan çalışmalarda da benzer sonuçlar bulunmuştur $(18,21,22)$. Bu sonuçlar ise literatürü destekler niteliktedir.

\section{Sonuç ve öneriler}

Yapılan bu araştırma sonucunda; bir üniversite hastanesinin dahili ve cerrahi kliniklerinde çalışan hemşirelerin kanıta dayalı hemşireliğe yönelik tutumlarının orta düzeyde olduğu, bilimsel toplantılara katılma ve mesleki yayınları takip etme gibi özelliklerin hemşirelerin kanıta dayalı hemşireliğe yönelik tutumlarını olumlu yönde etkilediği saptanmıştır.

Bu sonuçlar doğrultusunda, hemşirelerinin bilimsel toplantılara (kongre, sempozyum ve kurslar) katılımlarının desteklenmesi, bu amaçla gerekli izin ve maddi desteğin sağlanması, bilimsel faaliyetlerde aktif rol almaları ve mesleki yayınları/araştırma sonuçlarını takip edebilmeleri konusunda teşvik edilmesi önerilebilir. Ayrıca hemşirelerinin kanıta dayalı hemşirelik uygulamaları konusunda farkındalıklarını arttıracak hizmet içi eğitim programlarının hazırlanması da yararlı olacaktır.

5. Stevens KR. The impact of evidence-based practice in nursing and the next big ideas. Online J Issues Nurs 2013;18:4.

6. Kocaman G. Hemşirelikte kanıta dayalı uygulama. Hem Araş Geliş Derg 2003;2:61-9.

7. Estabrooks CA. Will evidence-based nursing practice make practice perfect? 1998. Canadian J Nurs Res 1999;30:273-94.

8. Öztürk Çopur E, Kuru N, Canbolat Seyman Ç. Hemşirelikte kanıta dayalı uygulamalara genel bakış. Sağlık Hem Yön Derg 2015;1:51-5. [CrossRef]

9. Demir $Y, A k B$, Bilgin NÇ, Efe $H$, Albayrak E, Çelikpençe $Z$, et al. Hemşirelik uygulamalarında araştırma sonuçlarının kullanımındaki engeller ve kolaylaştırıcı faktörler. J Contemp Med 2012;2:94-101. 
10. Güneş Ü. Hemşirelikte kanıta dayalı uygulama sürecinin adımları. Uluslararası Hakemli Hem Araş Derg 2017;9:171-87. [CrossRef]

11. Gerrish K, Ashworth P, Lacey A, Bailey J, Cooke J, Kendall S, McNeilly E. Factors influencing the development of evidence-based practice: a research tool. J Adv Nurs 2007;57:328-38. [CrossRef]

12. Melynk BM, Fineout-Overholt E, Stillwell SB, Williamson KM. Evidence-based practice: step by step-igniting a spirit of inquiry and essential foundation for evidence-based practice. Am J Nurs 2009;109:49-52. [CrossRef]

13. Leufer T, Cleary-Holdforth J. Evidence-based practice: improving patient outcomes. Nurs Stand 2009;23:35-9. [CrossRef]

14. Sitzia J. Barrier store search utilization: the clinical setting and nurses themselves. Intensive Crit Care Nurs 2002;18:230-43. [CrossRef]

15. Ayhan Y. Kanıta dayalı hemşireliğe yönelik tutum ölçeği'nin Türkçe'ye uyarlanması: geçerlik ve güvenirlik çalışması. Dokuz Eylül Üniversitesi: Sağlık Bilimleri Enstitüsü, Yüksek Lisans Tezi, İzmir: 2013.

16. Upton D, Upton P. Development of an evidence-based practice questionnaire for nurses. J Adv Nurs 2006;54:454-8. [CrossRef]

17. Thiel L, Ghosh Y. Determining registered nurses' readiness for evidence-based practice. Worldviews Evid Based Nurs 2008;5:18292. [CrossRef]

18. Ruzafa-Martinez M, Lopez-Iborra L, Madrigal-Torres M. Attitude towards evidence-based nursing questionnaire: development and psychometric testing in Spanish community nurses. J Eval Clin Prac 2011;17:664-70. [CrossRef]
19. Munroe D, Duffy P, Fisher C. Nurse knowledge, skills, and attitudes related to evidence-based practice: Before and after organizational supports. Medsurg Nurs 2008;17:55-60.

20. Melnyk BM, Fineout-Overholt E, Giggleman M, Cruz R. Correlates among cognitive beliefs, EBP implementation, organizational culture, cohesion and job satisfaction in evidence-based practice mentors from a community hospital system. Nurs Outlook 2010;58:301-8. [CrossRef]

21. Ayhan $Y$, Kocaman G, Bektaş M. "Kanıta dayalı hemşireliğe yönelik tutum ölçeği"nin Türkçe'ye uyarlanması: geçerlik ve güvenirlik çalışması. Hem Araş Geliş Derg 2015;17:21-35.

22. Dikmen Y, Filiz NY, Tanrıkulu F, Yılmaz D, Kuzgun H. Attitudes of Intensive Care Nurses towards Evidence-Based Nursing. Int J Health Sci Res 2018;8:138-43.

23. Yurtsever S, Altıok M. Kanıta dayalı uygulamalar ve hemşirelik. FÜ Sağlık Bil Derg 2006;20:159-166.

24. Merih YD, Coşkuner Potur D, Yılmaz Esencan T. Doğum sonu kliniklerinde çalışan ebe ve hemşireler kanıta dayalı uygulamaların neresinde? Sağlık Hem Yön Derg 2017;1:8-14. [CrossRef]

25. Aydın Y, Adıgüzel A, Topal EA. Ebe ve hemşirelerin bilimsel çalışmalara yönelik tutumlarının belirlenmesi. J Hum Rhythm 2015;1:168-75.

26. Koehn ML, Lehman K. Nurses' perceptions of evidence-based nursing practice. J Adv Nurs 2008;62:209-15. [CrossRef] 